\title{
Invertebrates and microbiota associated with aquatic macrophyte degradation in a shallow lake in southern Brazil
}

\author{
Edélti Faria Albertoni*, Andréa Luiza de Mattos de Moraes, Pablo Santos Guimarães, Cleber \\ Palma-Silva \\ Programa de Pós-Graduação em Biologia de Ambientes Aquáticos Continentais, Universidade Federal do Rio Grande, Rio Grande, \\ 96203-900, Rio Grande do Sul, Brazil *efalbertoni@gmail.com
}

Received: September 13, 2019 / Accepted: Dezember 8, 2019 / Published online: January 20, 2020

\begin{abstract}
Aquatic macrophytes are the main producers of organic matter in shallow aquatic ecosystems. They are also food sources for many herbivores. When macrophytes die, they enter the debris chain, are conditioned by microbial action and colonized by benthic invertebrates which remobilize nutrients from their biomass. In subtropical aquatic systems, the participation of shredder invertebrates has been questioned, highlighting the participation of fungi and bacteria in the degradation of organic matter. This study evaluated the degradation of two submerged aquatic macrophytes, Mayaca fluviatilis and Stuckenia pectinata, determining the quality of debris and microbiota and invertebrate trophic group density throughout the degradation process. Our results indicated that plants with lower polyphenol concentrations had higher degradation speeds. The shredders invertebrates had reduced abundance in both macrophytes, emphasizing the importance of bacteria and fungi in the nutrient cycling process in subtropical shallow lakes.
\end{abstract}

Keywords: Bactéria, decomposition, detritivorous invertebrates, fungi, Mayaca fluviatilis, Stuckenia pectinata.

\section{Invertebrados e microbiota associados à degradação de macrófitas aquáticas em um lago raso no sul do Brasil}

\begin{abstract}
Resumo
Macrófitas aquáticas são os principais produtores de matéria orgânica em ecossistemas aquáticos rasos, sendo fonte alimentar para uma série de herbívoros. Após sua morte, entram na cadeia de detritos, são condicionadas por ação microbiana e colonizados por invertebrados bentônicos, responsáveis pela remobilização dos nutrientes de sua biomassa. Em sistemas aquáticos subtropicais, a participação de invertebrados fragmentadores tem sido questionada, ressaltando a participação de fungos e bactérias na degradação da matéria orgânica. Este trabalho teve como objetivos avaliar a degradação de duas macrófitas aquáticas submersas, determinando a qualidade do detrito e a densidade da microbiota e de grupos tróficos de invertebrados ao longo do processo. Os resultados indicaram que a planta com menor concentração de polifenóis teve velocidade maior de degradação. Os invertebrados fragmentadores tiveram abundância reduzida em ambas macrófitas, ressaltando a importância de bactérias e fungos no processo de ciclagem de nutrientes em lagos rasos subtropicais.
\end{abstract}

Palavras-chave: Bactérias, decomposição, fungos, invertebrados detritívoros, Mayaca fluviatilis, Stuckenia pectinata.

\section{Introduction}

In the southern coastal plain of Brazil, approximately $40 \%$ of the land comprises shallow lakes and wetland ecosystems, with aquatic macrophytes present in high abundance and biodiversity (Rolon \& Maltchick 2006). These plants are the main primary producers, with large biomass and high growth rates (Albertoni, Palma-Silva, Trindade, \& Furlanetto, 2014). They are consumed by an extensive range of herbivores, including vertebrates and invertebrates (Lodge, 1991). After they die, they become debris and act as food resources and habitats for detritivores, mainly invertebrates, with fundamental roles in nutrient cycling and incorporation in primary production (Esteves \& Gonçalves, 2011; Carvalho,
Hepp, Palma-Silva, \& Albertoni, 2015).

Throughout the decomposition process, coarse particulate organic matter (CPOM), autochthonous or allochthonous, is transformed into fine particulate organic matter (FPOM) (Gonçalves, Martins, Ottoni, \& Couceiro, 2014). This transformation occurs through basic mechanisms such as leaching, conditioning by microbial action and colonization by benthic invertebrates (Webster \& Benfield, 1986; Graça, Bärlocher, \& Gessner, 2005). Decomposition rates may be accelerated by several factors: the influence of environmental variables, nutrient levels (e.g. nitrogen and phosphorus) (Andersen, Grasset, Thormann, Rochefort, \& Francez, 2010; Overbeek et al., 2018), the presence of 
chemical inhibitors (such as polyphenols and tannins), and the structure of microbial communities or aquatic invertebrates (Graça et al., 2005; Gonçalves Jr et al., 2014).

In temperate climates, shredder invertebrates are important for the decomposition of vegetal debris (Graça et al., 2005; Gonçalves Jr, Graça, \& Callisto, 2006). In tropical and subtropical environments, the virtual absence or low density of this group has been demonstrated for different debris, e.g. in aquatic macrophytes (Silva, Silveira, Palma-Silva, \& Albertoni, 2010; Carvalho et al., 2015; Albertoni, Hepp, Carvalho, \& Palma-Silva, 2018) and tree species (Telöken, Albertoni, \& Palma-Silva, 2011; Telöken, Hepp, Palma-Silva $\&$ Albertoni, 2014). In ecosystems with low shredder densities, microbial conditioning during the decomposition process is very important (Telöken et al., 2014; Santschi, Gounand, Harvey, \& Altermatt, 2017; Fogelman, Bilger, Holt, \& Matlaga, 2018).

In this context, we sought to determine leaf degradation coefficients, and evaluate the presence and relative importance of microbiota associated with the decomposition of two aquatic macrophyte species, M. fluviatilis and S. pectinata. Our hypothesis proposed that plants with higher quality debris (low polyphenol and high nitrogen concentrations) would decompose faster, favoring a higher density of bacteria and fungi. We also investigated the abundance of invertebrate functional feeding groups associated with this detritus, anticipating low shredder densities, reinforcing the importance of microbiota in aquatic macrophyte degradation in shallow subtropical aquatic ecosystems.

\section{Materials and Methods}

\section{Study Area}

The study was performed in a small urban lake $\left(32^{\circ} 01^{\prime} 40^{\prime \prime} \mathrm{S}, 52^{\circ} 05^{\prime} 40^{\prime \prime} \mathrm{W}\right)$ located in the Carreiros Campus of the Federal University of Rio Grande - FURG, Rio Grande, Rio Grande do Sul, Brazil. The lake has an approximate area of 1 ha and a maximum depth of $1.6 \mathrm{~m}$, which fluctuates according to annual precipitation, averaging between 1200 and $1500 \mathrm{~mm}$ (Alvares, Stape, Watches, Gonçalves, \& Sparovek, 2013). The climate of the region is subtropical humid (Cfa, according to the Köppen classification), with an average annual temperature of $13^{\circ} \mathrm{C}$ in winter and $>22^{\circ} \mathrm{C}$ in summer (Alvares et al., 2013). The lake has oligo-mesotrophic characteristics, with low primary productivity and low nutrient concentrations (PalmaSilva et al., 2013).

\section{Field sampling and processing}

The submerged aquatic macrophytes; S. pectinata (L.) Börner and M. fluviatilis Aubl., were collected and air dried in the laboratory for approximately two weeks. To determine degradation coefficients, we incubated materials in litter bags. Bag dimensions were $20 \mathrm{~cm} \times 30 \mathrm{~cm}$, with $1 \mathrm{~cm}^{2}$ holes in the upper mesh and $1 \mathrm{~mm}^{2}$ holes in the lower mesh. We used 20 litter bags for each plant species, and incubated $10 \mathrm{~g}$ of debris (initial dry mass). The bags remained in the lake at an average depth of $50 \mathrm{~cm}$ from the sediment in January 2016. On incubation days $1,3,7$ and 18 , we removed five sample replicates and measured limnological variables using a multiparameter probe $\left(\operatorname{Horiba}^{\circledR}\right)$. During the study, we measured mean dissolved oxygen in the lake; $8.61 \pm 0.37$ mg. $\mathrm{L}^{-1}$, electrical conductivity $71.2 \pm 13.5 \mu \mathrm{S} . \mathrm{cm}^{-1}$, temperature $25.02 \pm 0.37^{\circ} \mathrm{C}$, turbidity of $53.8 \pm 2.65 \mathrm{NTU}$, and $\mathrm{pH}$ of $6.37 \pm 1.69$.

For each collection, one bag was used for microbial debris analysis, and four to determine dry mass and leaf degradation coefficient (k) (Graça et al., 2005), and associated invertebrates. Dry mass was determined by oven drying at $35^{\circ} \mathrm{C}$ to a constant mass. Invertebrates were separated from the debris using a sieve (mesh $250 \mu \mathrm{m}$ ) and fixed in $80 \%$ Rose Bengal stained alcohol. They were screened using a stereomicroscope, and identified to the lowest possible taxonomic level (Merritt, Cummins, \& Berg, 2008; Domínguez \& Fernández, 2009). We also determined nitrogen concentrations, total phosphorus and organic carbon in the debris, according to Rice, Baird, Eaton, \& Clesceri (2012), and polyphenol levels following the method of Graça et al. (2005).

For microbial analysis, we followed the methodology of Hickenbick, Ferro, and Abreu (2004). We fixed biological material in tubes, using $1 \mathrm{~cm}^{2}$ of $S$. pectinata leaf and four leaves of $M$. fluviatilis in $2.5 \mathrm{~mL} 3.7 \%$ formaldehyde. Afterwards, the material was sonicated in an ultrasonic homogenizer (Qsonica ${ }^{\circledR}$ ) adjusted to $25 \mathrm{~W}$, with an amplitude of $60 \mathrm{~A}$. Samples on ice, were sonicated over two 30 -second pulses, with 10 second intervals.

Samples were then vacuum filtered through a nucleopore membrane filter $(0.2 \mu \mathrm{m}$ pore) and rendered darker with "Irgalan Black". In a laminar flow hood, the filtered samples were stained with 10 drops of acridine orange fluorochrome for $10 \mathrm{~min}$, and then filtered and washed twice in distilled water to remove excess dye. To generate triplicate semipermanent slides, the dry filters containing samples were placed on a histological slide with a drop of mineral oil, and sealed with a coverslip and enamel. The samples were identified, and slides were stored at $5{ }^{\circ} \mathrm{C}$ for preservation until counts were made.

Slide samples were counted under a fluorescence light microscope (Olympus BX51), using a WB optical filter, DM500 dichroic mirror, BP450-480 nm excitation filter, and BA515 barrier filter. Thirty bacteria fields and 150 fields were photographed to assess the abundance of hyphae and fungal spores, respectively. All fields were randomly selected across slides. For counting, we used the Image ${ }^{\circledR}$ program (Wayne Rasband, National Institutes of Health, USA, Version 1.48d).

\section{Data Analysis}

To determine the degradation coefficient $(\mathrm{k})$, we used the exponential decay model, $\mathrm{M}_{\mathrm{t}}=\mathrm{M}_{0}{ }^{\mathrm{e}-\mathrm{kt}}$, where $\mathrm{M}_{\mathrm{t}}$ is the remaining mass at time $t$ (days), $M_{0}$ is the initial mass, e is the basis of the Napierian logarithm, and $\mathrm{k}$ is the degradation coefficient (Graça et al., 2005). We constructed a linear regression to fit the initial dry mass (air-dried) with the dry mass of those processed during incubation periods (ovendried). After test the data normality, the nitrogen, phosphorus, carbon and polyphenol concentrations between the two plants were compared using Student's t-tests, for 
each day of debris removal.

Invertebrates associated with the debris were investigated using taxa richness, and the Shannon diversity index $\left(\mathrm{H}^{\prime}\right)$ (Magurran, 2004), and categorized according to functional feeding groups (FFG) (Tomanova, Goitia, \& Heles, 2006; Merritt, Cummins, \& Berg, 2008; Domínguez \& Fernandez, 2009). Organism densities between the two plants for each period, were compared using one-way ANOVA, and diversity indices were assessed using Student's t-tests with Monte Carlo randomization. Microbiota densities over time between the two plants were compared using two-way ANOVA, where factor one was microbiota density (bacteria, hyphae and spores) and factor two was time (days $0,1,3,7,18$ ). All data analyses were performed on free Past software for scientific data analysis (Hammer, Harper, \& Ryan 2001).

\section{Results and Discussion}

The degradation rate was similar for the two plants until the fourth day, when $S$. pectinata demonstrated greater mass loss. By the $18^{\text {th }}$ day of the degradation period, M. fluviatilis showed a $40 \%$ loss of dry mass, at a degradation rate of $0.114 \mathrm{~d}^{-1}$. During this same period, the mass loss of S. pectinata was $67 \%$, at a rate of $0.243 \mathrm{~d}^{-1}$, indicating a decomposition process approximately twice as fast as $M$. fluviatilis (Figure 1).

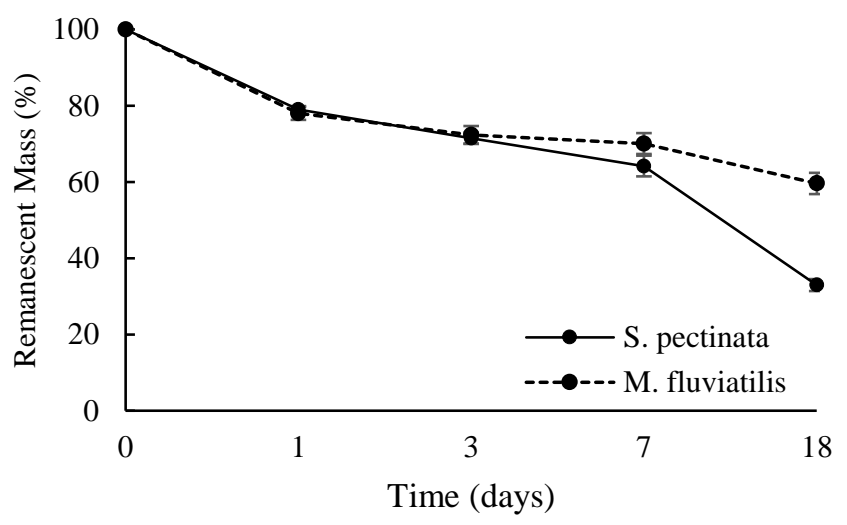

Figure 1. Dry mass decay (bar = standard error) of S. pectinata and $M$. fluviatilis debris over indicated decomposition times, in a shallow subtropical lake in southern Brazil (0 to $18=$ incubation days).

In an extensive review of degradation rates in aquatic macrophytes in Brazil, Gonçalves-Jr. et al. (2014) did not mention either species used in their research. Other studies performed near the study site, cited the degradation rate of $S$. pectinata (syn. Potamogeton pectinatus) as $\mathrm{k}=0.019 \mathrm{~d}^{-1}$ (Carvalho, Hepp, Palma-Silva, \& Albertoni, 2015).

Despite its abundance in lentic water bodies throughout Brazil, data on $M$. fluviatilis decomposition are outdated, been cited $80 \%$ of remained mass after 40 days decomposition, in a tropical reservoir in summer (Silva, Oliveira, Escarpinati, Fonseca-Gessner, \& Paula, 2011)Several factors influence the rate of decomposition in aquatic systems; temperature (Song, Yan, Cai, \& Jiang, 2013), nutrient concentrations (Webster \& Benfield, 1986), and the composition of decomposing microbial communities (Shilla, Asaeda, Fugino, \& Sanderson, 2006).

\section{Nutrients}

Debris nutrient concentrations differed between both macrophyte plants at each incubation period. Phosphorus levels were higher in $S$. pectinata $(p=0.048)$, and for both plants there was a decrease in phosphorus levels at experiment end. Phosphorus concentrations in S. pectinata ranged from 39.59 to $19.59 \mu \mathrm{g}^{-g^{-1}}$, with maximum levels on the seventh day of incubation. Phosphorus concentrations in M. fluviatilis ranged from 27.53 to $12.30 \mu \mathrm{g} \cdot \mathrm{g}^{-1}$, peaking on the third day of incubation.

However, nitrogen concentrations in debris showed contrary behaviors between the two plants, with $M$. fluviatilis showing debris enrichment throughout decomposition, only decreasing on the 18th day. As with phosphorus, there were significant differences between nitrogen concentrations in the two plants $(p=0.044)$. In $M$. fluviatilis, nitrogen concentrations ranged from 1.67 (initial concentration) to $2.78 \mathrm{mg} . \mathrm{g}^{-1}$ (third day of incubation). In S. pectinata, values ranged from 1.51 (first day) to $2.56 \mathrm{mg}^{-g^{-1}}$ (18 ${ }^{\text {th }}$ day).

Organic carbon also showed significant differences between the two plants $(p=0.008)$. Levels ranged from $7.42 \%$ to $2.91 \%$ in S. pectinata, and from $5.19 \%$ to $2.04 \%$ in M. fluviatilis. Unlike M. fluviatilis, S. pectinata detritus showed a tendency to increase organic carbon concentrations, which may reflect increases in fungal hyphae densities, contributing to higher concentrations of carbon and other nutrients, incorporating the biomass of these microorganisms.

Polyphenol levels were lower in $M$. fluviatilis at experiment end (1,567 UDO g-1 Dry Mass) when compared to $S$. pectinata $\left(2,967 \mathrm{UDO}_{\mathrm{g}-}{ }^{1} \mathrm{DM}\right)(p=0.036)$. Polyphenol concentrations are indicators of debris palatability, as these compounds act as plant defenses (Lodge, 1991).

\section{Invertebrates}

We identified 25 invertebrate taxa associated with debris of the two plants. Nineteen were found in M. fluviatilis and 14 in S. pectinata (Table 1). The taxa found in M. fluviatilis had a higher diversity index $\left(\mathrm{H}^{\prime}=2.01\right)$. The dominant organism in $M$. fluviatilis came from the Chironomidae (50\%), predominantly Chironominae (collector), with $28 \%$ relative abundance, followed by Tanypodinae (predator, $22 \%$ ) and copepod Cyclopoida (collector, 13\%) (Table 2). In contrast, $S$. pectinata had a 14 taxa richness and a lower diversity index $(\mathrm{H}=1.84, p<0.010)$. The predominant groups were Tanypodinae (32\%), Chironominae (20\%) and Cypridopsis vidua (Ostracoda, 15\%), although these levels were only recorded at the beginning of the degrading process (Table 2). Diversity indices showed significant differences ( $p=0.010)$ between debris from the two plants.

The functional feeding groups found were predator $(\mathrm{P})$, collector $(\mathrm{C})$, scraper $(\mathrm{S})$, and shredder $(\mathrm{Sr})$. Predators were predominant in both macrophytes, with $49 \%$ and $44 \%$ in $M$. fluviatilis and $S$. pectinata, respectively. Collectors represented $42 \%$ and $39 \%$, and shredders represented $2 \%$ and $0.4 \%$, respectively in $M$. fluviatilis and $S$. pectinata. Scrapers represented $11 \%$ of organisms in both debris. This relative proportion of FFGs in debris was similar to other foliar degradation studies conducted in the same lake 
(Telöken et al., 2011). The low abundance of shredders participating in foliar degradation processes confirmed the results of previous studies in subtropical lakes (Silva et al., 2010; Telöken et al., 2011; Carvalho et al., 2015; Albertoni et al., 2018). Several authors have shown that the detritivorous invertebrate communities that colonizes debris, are poorly represented by shredders in tropical and subtropical regions (Capello, Marchese \& Ezcurra de Drago, 2004; Gonçalves Jr. et al., 2006; Carvalho \& Uieda, 2009). Decomposition at low latitudes means increased participation of microbiota (bacteria and fungi) as decomposers, with little influence from detritivorous fragmentation (Irons, Oswood, Stout, \& Pringle, 1994).

Table 1. Presence (+) of detrivorous invertebrates associated with Mayaca fluviatilis and Stuckenia pectinata debris in a shallow subtropical lake in southern Brazil. FFG: Functional feeding groups, predator $(\mathrm{P})$, collector $(\mathrm{C})$, scraper $(\mathrm{S})$, shredder $(\mathrm{Sr})$

\begin{tabular}{|c|c|c|c|}
\hline Taxa & M. fluviatilis & S. pectinata & FFG \\
\hline Nematoda & + & & $\mathrm{P}$ \\
\hline Hirudinea Glossiphoniidae & + & + & $P$ \\
\hline Oligochaeta & + & + & $\mathrm{C}$ \\
\hline Hydracarina & + & + & $\mathrm{P}$ \\
\hline $\begin{array}{l}\text { Platyhelminthes } \\
\text { Turbellaria }\end{array}$ & + & & $\mathrm{P}$ \\
\hline Mollusca Planorbidae & + & & S \\
\hline Mollusca Ampullaridae & & + & S \\
\hline Cladocera Daphnidae & & + & $\mathrm{C}$ \\
\hline Copepoda Cyclopoida & + & + & $\mathrm{P}$ \\
\hline $\begin{array}{l}\text { Ostracoda Cipridopsis } \\
\text { vidua }\end{array}$ & & + & $\mathrm{C}$ \\
\hline $\begin{array}{l}\text { Ostracoda Cytheridella } \\
\text { islovayi }\end{array}$ & + & & $\mathrm{Sr}$ \\
\hline $\begin{array}{l}\text { Ostracoda Strandesia } \\
\text { cuspida }\end{array}$ & + & & $\mathrm{Sr}$ \\
\hline Ephemeroptera Caenidae & + & + & S \\
\hline Ephemeroptera Baetidae & + & & S \\
\hline Trichoptera Leptoceridae & + & & $\mathrm{C}$ \\
\hline Trichoptera Hidroptilidae & + & + & $\mathrm{C}$ \\
\hline Odonata Coenagrionidae & + & & $\mathrm{P}$ \\
\hline Odonata Aeshnidae & & + & $\mathrm{P}$ \\
\hline Hemiptera Cicadellidae & + & & $P$ \\
\hline Hemiptera Saldidae & & + & $\mathrm{P}$ \\
\hline Coleoptera Hydrophilidae & + & & $\mathrm{P}$ \\
\hline Diptera Dolichopodidae & + & & $\mathrm{P}$ \\
\hline Diptera Culicidade & & + & $\mathrm{Sr}$ \\
\hline Diptera Chironominae & + & + & $\mathrm{C}$ \\
\hline Diptera Tanypodinae & + & + & $P$ \\
\hline
\end{tabular}

Due to the phenolic toxicity of some plants, mainly from tannins, these compounds inhibit herbivore consumption, as in high concentrations the plants are unpalatable to phytophages, inhibiting the action of digestive enzymes and leaf consumption (Monteiro, Allbuquerque, \& Araújo 2005). The great richness and diversity of macrophytes with lower polyphenol concentrations, reinforces the role of these compounds in herbivory resistance. However, this richness and diversity is not reflected in decomposition rates, as they are influenced by higher numbers of shredder invertebrates, which use leaf debris as food (Carvalho \& Uieda, 2009). Our FFG data showed a virtual absence of this invertebrate group, which may be related to their influence on decomposition speeds. As no herbivory occurred directly, other groups (collectors, scrapers and predators) were favored by debris, using it primarily as a habitat, and the macrophyte with lower decomposition speed favors the establishment of a more diverse community.

Table 2. Succession of invertebrates in detritus from Mayaca fluviatilis (M) and Stuckenia pectinata (S) over decomposition times in a shallow subtropical lake in southern Brazil ( 1 to $4=0$ to 18 incubation days).

\begin{tabular}{lcccc||cccc}
\hline \multirow{2}{*}{ Taxa } & \multicolumn{4}{c||}{ Stuckenia pectinata } & \multicolumn{3}{c}{ Mayaca fluviatilis } \\
\cline { 2 - 8 } & S1 & S2 & S3 & S4 & M1 & M2 & M3 & M4 \\
\hline Oligochaeta & 0 & 0 & 1 & 3 & 2 & 5 & 6 & 58 \\
Ostracoda & 35 & 3 & 0 & 1 & 2 & 1 & 4 & 0 \\
Copepoda & 1 & 22 & 6 & 3 & 11 & 49 & 8 & 9 \\
Caenidae & 0 & 0 & 15 & 13 & 1 & 6 & 18 & 36 \\
Chironominae & 5 & 5 & 3 & 38 & 6 & 3 & 53 & 101 \\
Tanypodinae & 0 & 6 & 52 & 25 & 14 & 23 & 35 & 53 \\
Others & 0 & 8 & 3 & 5 & 30 & 2 & 9 & 30 \\
\hline
\end{tabular}

\section{Microbiota}

Microbiota densities (bacteria, hyphae and spores) were higher in M. fluviatilis macrophyte (Table 3). Our results showed that microbial colonization behaviors in debris was different between the two macrophytes. Although a significant difference was observed between plants in terms of hyphae density ( $M$. fluviatilis had the greater density, $p=$ 0.005 ), bacterial colonization was higher at the beginning of the decomposition process in $S$. pectinata, whereas for $M$. fluviatilis, the highest density was fungal hyphae (Table 3). When we evaluated the relative abundance of microbiota, it was noted that, independent of the density, fungi (hyphae and spores) were highly important for the degradation process of S. pectinata. On the other hand, for M. fluviatilis, bacterial colonization tended to increase in importance relative to the end of the degradation process of this plant.

Although it is accepted that fungi dominate microbial communities in riverbeds and streams at decomposition onset (Suberkroop \& Klug, 1976), several studies of lakes have shown that bacteria are dominant in early decomposition periods (Shilla, Asaeda, Fujino, \& Sanderson, 2006). Several studies have shown that microbial colonization of macrophyte detritus contrasts between streams and lakes and wetlands, where fungi are the main decomposers in streams, whereas bacteria are in lentic systems (Gaur, Singhal, \& Hasija, 1992). Romaní, Fisher, Mille-Lindblom, \& Tranvik (2006) demonstrated that complex interactions between fungi and bacteria occurred in 
aquatic habitats.

The qualitative structure of debris (cell wall composition, polysaccharides and supporting tissues) could cause alterations between higher bacterial activity as decomposers of more fragile supporting structures (Schlickeisen, Tietjen, \& Arsuffi, 2003). Aquatic hyphomycetes (fungi) dominate vegetal decomposition in streams, because their hyphae penetrates leaf surfaces to enzymatically degrade complex carbon structures (Gessner \& Chauvet, 1994). These authors also state that bacteria colonize the debris later, due to poor invasive capacity, as they are more associated with debris surfaces. Our results showed evidence of increased bacterial colonization at the beginning of $S$. pectinata degradation processes, and increased bacterial colonization importance at the end of $M$. fluviatilis degradation processes.
While $S$. pectinata displayed higher polyphenol concentrations, it generated lower densities of microbiota organisms. Although this macrophyte had higher nitrogen concentrations initially, this suggested that debris conditioning was primarily influenced by polyphenol concentrations. Fungal colonization predominates in plants with higher nitrogen concentrations (Cummins, Petersen, Howard, Wuycheck, \& Holt, 1973).

The release of carbon and nutrients through the decomposition of submerged aquatic macrophyte debris is a critical process in shallow lake ecosystems, as these plants represent one of the largest components of organic matter in these ecosystems (Song, Yan, Cai, \& Jiang, 2013).

Table 3. Density (ind. $\mathrm{cm}^{-2} \times 10^{6}$ ) and relative abundance (\%) of bacteria, hyphae, and spores during decomposition of Stuckenia pectinata (S) and Mayaca fluviatilis (M) in a shallow subtropical lake, in Brazil.

\begin{tabular}{lcccccccccc}
\hline \multirow{2}{*}{ Microbiota } & \multicolumn{9}{c}{ Stuckenia pectinata } & \multicolumn{7}{c}{ Mayaca fluviatilis } \\
\cline { 2 - 11 } & S0 & S1 & S2 & S3 & S4 & M0 & M1 & M2 & M3 & M4 \\
\hline Bacteria & 6.02 & 2.35 & 1.12 & 5.97 & 0.54 & 2.71 & 3.57 & 3.25 & 4.71 & 6.89 \\
Hyphae & 2.34 & 1.77 & 1.63 & 0.68 & 0.36 & 6.55 & 9.11 & 7.29 & 1.64 & 5.63 \\
Spores & 0.94 & 0.10 & 2.37 & 4.06 & 0.18 & 4.65 & 1.94 & 4.53 & 1.25 & 0.65 \\
\hline \multicolumn{1}{c}{ Relative Importance $(\%)$} \\
Bacteria & 64.8 & 55.6 & 21.9 & 55.8 & 50.5 & 19.5 & 24.5 & 20.7 & 62.0 & 52.1 \\
Hyphae & 25.1 & 42.0 & 31.8 & 6.4 & 33.1 & 47.1 & 62.4 & 46.5 & 21.6 & 42.6 \\
Spores & 10.1 & 2.3 & 46.3 & 37.9 & 16.5 & 33.4 & 13.3 & 28.8 & 16.5 & 5.0 \\
\hline
\end{tabular}

We showed that macrophytes displayed differences in nutritional content, and in the richness and diversity of detritivore invertebrates. These differences did not corroborate previous studies conducted in larger numbers in streams, especially for direct relationships between higher degradation rates, lower polyphenol concentrations and higher nitrogen concentrations, which increases debris palatability (Biasi et al., 2013). In their study, Rezende et al. (2019) found a positive correlation between hyphomycete colonization and invertebrate richness, as a function of increased debris palatability, and a high density of shredder invertebrates as influencers of degradation velocity. Some factors may account for these differences: e.g. the low density of shredder invertebrates in tropical and subtropical lentic systems (Gonçalves, Graça \& Callisto 2007; Albertoni, Hepp, Carvalho \& Palma-Silva 2018). Longer degrading macrophytes may favor the permanence of a more structured debris-associated community (Slight, Moretti, Gonçalves, \& Callisto 2010) and may explain the higher density and richness of invertebrates in M. fluviatilis debris. Differential microbiota colonization during the degradation process may also be an influencing factor, as both plants showed distinct behaviors in relation to the main microbiota groups: bacteria levels tended to increase in M. fluviatilis, while fungi levels increased in density in $S$. pectinata. Fungi and bacteria act together in the decomposition and mineralization of debris in aquatic environments, with degradation involving complex interactions between decomposers, which may be antagonistic (competitive) or synergistic (facilitative) (Mille-Lindblom \& Tranvik, 2003). Future studies should quantify the growth rates of different microbiota groups, evaluating interactions between the different decomposers.

\section{Conclusion}

The role of different functional feeding groups of invertebrates and microbiota in the degradation of organic matter may be related to the characteristics of debris material. Our hypothesis was partially confirmed as nutrient concentration was less influential on invertebrate colonization and conditioning by microorganisms. Our results also showed a low abundance of shredder invertebrates in subtropical shallow lake ecosystems, emphasizing the importance of fungi and bacteria in degrading organic matter. Although our work has spatial and temporal limitations (performed in one lake and over a specific period), we believe our data indicates patterns of microbiota succession in aquatic macrophyte detritus, in shallow aquatic ecosystems, such as shallow lakes and wetlands. These data relate the abundance of microbiota in aquatic macrophyte debris in subtropical lentic environments, and while preliminary, our data indicates that more research on ecological processes could elucidate the roles of invertebrates and microorganisms in nutrient cycling and energy flow in these ecosystems. 


\section{References}

Albertoni, E. F., Palma-Silva, C., Trindade, C. R. T., \& Furlanetto, L. M. (2014). Field evidence of the influence of aquatic macrophytes on water quality in a shallow eutrophic lake over a 13-year period. Acta Limnologica Brasiliensia, 26(2), 176-185. doi: 10.1590/S2179975X2014000200008

Albertoni, E. F., Hepp, L. U., Carvalho, C. \& Palma-Silva, C. (2018). Invertebrate composition in submerged macrophyte debris: habitat and degradation time effects. Ecologia Austral 28, 93-103. Recovered from

http://hdl.handle.net/20.500.12110/ecologiaaustral_v028_n01_p093

Alvares, C. A., Stape, J. L., Sentelhas, P. C., Gonçalves, J. L. M., Sparovek, G. (2013) Köppen's climate classification map for Brazil. Meteorologische Zeitschrift 22(6), 711-728. doi: 10.1127/09412948/2013/0507

Andersen, R., Grasset, L., Thormann, M.N., Rochefort, L., \& Francez, A. J. (2010). Changes in microbial community structure and function following Sphagnum peatland restoration. Soil Biological and Biochemical, 42, 291301. doi: 10.1016/j.soilbio.2009.11.006

Capello, S., Marchese, M., \& Ezcurra de Drago, I. (2004). Descomposición y colonización por invertebrados de hojas de Salix humboldtiana em la llanura aluvial del Río Paraná Medio. Amazoniana, 18, 125-143.

Carvalho, C., Hepp, L. U., Palma-Silva, C., \& Albertoni, E. F. (2015). Decomposition of macrophytes in a shallow subtropical lake. Limnologica 53, 1-9. doi: 10.1016/j.limno.2015.04.003

Carvalho, E. M., \& Uieda, V. S. (2009). Diet of invertebrates sampled in leafbags incubated in a tropical headwater stream. Zoologia, 26(4), 694704. doi: 10.1590/S1984-46702009000400014

Cummins, K. W., Petersen, R. C., Howard, F. O., Wuycheck, J. C., \& Holt, V. I. (1973). The utilization of leaf litter by stream detritivores. Ecology 54(2), 336-345. doi:10.2307/1934341

Domínguez, E., \& Fernández H. R. (ed.). (2009). Guía para la determinación de los artrópodos bentónicos sudamericanos. $2^{\mathrm{a}}$ Ed. Tucumán: Editorial Universitaria de Tucumán. pp. 654.

Esteves, F. D. A., \& Gonçalves Jr, J. F. (2011). Etapas do metabolismo aquático. Fundamentos de limnologia. (3 ${ }^{\mathrm{a}}$ Ed., Cap. 7, 119-124), Interciência, Rio de Janeiro.

Fogelman, K.J., Bilger, M. D., Holt, J.R., \& Matlaga, D. P. (2018). Decomposition and benthic macroinvertebrate communities of exotic Japanese knotweed (Fallopia japonica) and American sycamore (Platanus occidentalus) detritus within the Susquehanna River. Journal of Freshwater Ecology, 33(1), 299-310. doi: $10.1080 / 02705060.2018 .1458660$

Gaur, S., Singhal, P. K., \& S. K. Hasija (1992) Relative contributions of bacteria and fungi to water hyacinth decomposition. Aquatic Botany, 43, 1-15. doi: 10.1016/0304-3770(92)90010-g

Gessner M. O. \& Chauvet, E. (1994) Importance of stream microfungi in controlling breakdown rates of leaf litter. Ecology 75, 1897-1817

Gonçalves Jr, J. F., Graça, M. A. S., \& Callisto, M. (2006). Leaf-litter breakdown in 3 streams in temperate, Mediterranean, and tropical Cerrado climates. Journal of North American Benthological Society,25(2), 344355. doi: $10.1899 / 0887-3593$

Gonçalves Jr, J. F., Graça, M. A. S., \& Callisto, M. (2007). Litter decomposition in a cerrado savannah stream is retarded by leaf toughness, low dissolved nutrients and a low density of shredders. Freshwater Biology, 52, 1440-1451. doi: 10.1111/j.1365-2427.2007.01769.x

Gonçalves Jr., J. F., Martins, R. T., Ottoni, B. M. P., \& Couceiro, S. R. M. (2014). Uma visão sobre a decomposição foliar em sistemas aquáticos brasileiros. In: Hamada, N.,

Nessimian, J. L., Querino, R. B. (Eds) Insetos aquáticos na Amazônia brasileira: taxonomia, biologia e ecologia. (Cap. 6, pg 89-116) Manaus: Editora do INPA.

Graça, M. A., Bärlocher, F., \& Gessner, M. O. (Eds.). (2005). Methods to study litter decomposition: a practical guide. Springer Science \& Business Media.

Hammer, Ø., Harper, D.A.T., \& Ryan, P.D. (2001). PAST: Paleontological

Statistics Software Package for Education and Data Analysis.

Palaeontology $\quad$ Electronic, $4, \quad 1-9 . \quad$ https://palaeoelectronica.org/2001_1/past/past.pdf

Hickenbick, G. R., Ferro, A. L., \& Abreu, P. C. O. V. (2004). Produção de detrito de macrófitas emergentes em uma marisma do estuário da lagoa dos Patos: taxas de decomposição e dinâmica microbiana. Atlântica, 26, (1), 61-75. Recovered from http://repositorio.furg.br/handle/1/3430

Irons, J. G., Oswood, M. W., Stout, R. J. \& Pringle, C. M. (1994). Latitudinal patterns in leaf litter breakdown: is temperature really important? Freshwater Biology, 32, 401-411. doi: 10.1111/j.13652427.1994.tb01135.x

Ligeiro, R., Moretti, M. S., Gonçalves, J. F., Callisto, M. (2010) What is more important for invertebrate colonization in a stream with lowquality litter inputs: exposure time or leaf species? Hydrobiologia, 654(1), 125-136.

Lodge, D.M. (1991). Herbivory on freshwater macrophytes. Aquatic Botany, 41, 195-224. doi: 10.1016/0304-3770(91)90044-6

Magurran, A. 2004. Measuring Biological Diversity. Oxford, Blackwell Publishing. pp. 256

Merritt, R. W., Cummins, K. W. \& Berg, M. B. (2008). An Introduction to the Aquatic Insects of North America. Dubuque, Kendall/Hunt Publishing Co. pp. 1158

Mille-Lindblom C., \& Tranvik L. J. (2003). Antagonism between bacteria and fungi on decomposing aquatic plant litter. Microbial Ecology 45, 173-182. doi:10.1007/s00248-002-2030-z

Monteiro, J.M., Allbuquerque, U.P., Araújo, E.L. (2005) Taninos: uma abordagem da química à ecologia. Química Nova, 28, 892-896.

Overbeek, C. C., van der Geest, H. G., van Loon, E. E., Klink, A. D., van Heeringen, S. F., Harpenslager, S. F., \& Admiraal, W. (2018). Decomposition of aquatic pioneer vegetation in newly constructed wetlands. Ecological Engineering, 114, 154-161. doi: 10.1016/j.ecoleng.2017.06.046

Rezende R. S., Medeiros A. O., Gonçalves J. F. Jr, Feio M. J., Pereira Gusmão E., de Andrade Gomes V. A., Calor A., \& Almeida J. (2019) Patterns of litter inputs, hyphomycetes and invertebrates in a Brazilian savanna stream: a process of degradative succession. Journal of Tropical Ecology 35, 297-307. doi: 10.1017/S0266467419000269

Rice, E. W., Baird, R. B., Eaton, A. D. \& Clesceri, L. S. (2012) Standard Methods for Examination of Water and Wastewater, 22nd ed. Washington, DC, American Public Health Association, American Water Works Association and Water Environment Federation

Rolon, A. \& Maltchick, L. (2006). Environmental factors as predictors of aquatic macrophyte richness and composition in wetlands of southern Brazil. Hydrobiologia, 556, 221-231. doi:10.1007/s10750-005-1364-1

Romaní, A. M., Fischer, H., Mille-Lindblom, C., \& Tranvik, L. J. (2006) Interactions of Bacteria and Fungi on Decomposing Litter: Differential Extracellular Enzyme Activities. Ecology, 87(10), 2559-2569. Recovered from http://www.jstor.org/stable/20069266

Santschi, F., Gounand, I.Harvey, E., \& Altermatt, F. (2018). Leaf litter diversity and structure of microbial decomposer communities modulate litter decomposition in aquatic systems. Functional Ecology 32,522532. doi: 10.1111/1365-2435.12980

Shilla, D., Asaeda, T., Fujino, T., \& Sanderson, B. (2006). Decomposition of dominantsubmerged macrophytes: implications for nutrient release in Myall Lake, NSW, Australia. Wetland Ecology and Management 5(14), 427-433. doi: 10.1007/s11273-006-6294-9

Silva, F. L., Oliveira, H. R. N., Escarpinati, S., C.; Fonseca-Gessner, A. A. \& Paula, M. C. (2011). Colonization of leaf litter of two aquatic macrophytes, Mayaca fluviatilis, Aublet and Salvinia auriculata, Aublet by aquatic macroinvertebrates in a tropical reservoir. AmbiAgua, 6 (1), 30-39. doi:10.4136/ambi-agua.171

Silva, J. S., Silveira, W. T., Albertoni, E. F., \& Palma-Silva, C. (2010). Diversity of Chironomidae (Diptera) in decomposing Nymphoides indica (L.) Kuntze in two subtropical lakes with different trophic conditions. Pan-American Journal of Aquatic Sciences, 5(4), 557-571. Recovered from http://repositorio.furg.br/handle/1/3089

Song, N., Yan, Z. S., Cai, H. Y., \& Jiang, H. L. (2013). Effect of temperature on submerged macrophyte litter decomposition within sediments from a large shallow and subtropical freshwater lake. Hydrobiologia, 714, 131- 144. doi: 10.1007/s10750-013-1529-2

Suberkroop, K. \& Klug, M. J. (1976). Fungi and bacteria associated with leaves during processing in a woodland stream. Ecology, 57, 707-719. doi: $10.2307 / 1936184$

Palma-Silva, C., Marinho, C.C., Albertoni, E.F., Giacomini, I.B., Figueiredo-Barros, M.P., Furlanetto, L.M., Trindade, C.R.T., \& Esteves, F.A. (2013). Methane emissions in two small shallow neotropical lakes: the role of temperature and trophic level. Atmospheric Environment, 81, 373-379 doi: 10.1016/j.atmosenv.2013.09.029 
Telöken, F., Albertoni, E.F., Palma-Silva, C. (2011). Leaf degradation of Salix hum-boldtiana Willd, (Salicaceae) and invertebrate colonization in a subtropical lake (Brazil). Acta Limnologica Brasiliensia, 23(1), 30-41. doi:10.4322/actalb.2011.016

Telöken, F., Albertoni, E.F., Hepp, L. U. \& Palma-Silva, C. (2014). Invertebrados aquáticos associados a serapilheira de Salix humboldtiana em um riacho subtropical. Ecología Austral 24, 220-228. Recovered from http://ojs.ecologiaaustral.com.ar/index.php/Ecologia_Austral/article/view 125

Tomanova, S., Goitia, E., \& Heles, J. (2006). Trophic levels and functional feeding groups of macroinvertebrates in neotropical streams. Hydrobiologia, 556, 251-264. doi:10.1007/s10750-005-1255-5

Webster, J.R., \& Benfield, E.F. (1986). Vascular plant breakdown in freshwater ecosystems. Annual Review of Ecology and Systematics 17, 567-594. doi:10.1146/annurev.es.17.110186.003031

\section{License: Creative Commons CC BY 4.0}

This article was published with open access for distribution under the terms of the Creative Commons Attribution License, which allows unrestricted use, distribution, and reproduction in any medium, provided the original work is properly cited. 